\title{
CHAPTER 7 \\ THE CHOICE OF DEVELOPMENT MANAGEMENT \\ DRIVERS OF THE SOCIO-ECONOMIC SYSTEM \\ OF THE NATIONAL AND INTERNATIONAL LEVEL BASED ON THE RESULTS OF FORECASTING
}

\section{Kononova I. V.}

\section{INTRODUCTION}

Any country is a complicated social and economic system that has a tendency to develop. However, to achieve the goals, development must be managed with appropriate mechanisms. Development control drivers are such mechanisms designed to intensify the impulses of development, transforming their impact from potential to real. Such management should be proactive, that is why it should be based on the forecasting results. From the point of view of Ukrainian economic science, the importance of the problem research is on the advance because of strengthening the integration processes with the European Union have been declared in Ukraine recently. In this regard, today's Ukrainian economy is closely dependent on the European Union, and internal plans and trends of the western neighbours are directly reflected at the level of the national economy's development. Taking this into account, in the current context, the implementation of the forecasting of the EU countries' economic development is extremely relevant.

\subsection{Determination of the main tendencies of the parameters of the functioning of the European Union and Ukraine}

\section{as the basis for the choice of a development management system}

As some scholars have rightly pointed out, a good standard of living, social and economic well-being, and environmental preservation are European strategic goals (Kranjac, Sikimić, Tomić, Vapa-Tankosić, 2017) ${ }^{1}$. According to studies, the European Union intends to build the growing and stable European economy, the most competitive and dynamic

\footnotetext{
${ }^{1}$ Kranjac, M., Sikimić, U., Tomić, S., \& Vapa-Tankosić, J. (2017). The Contribution of EU Funds to Wellbeing and Sustainable Development in Central European Countries. European Journal of Sustainable Development, 6 (1), 85-102. doi: https://doi.org/10.14207/ejsd.2017.v6n1p85
} 
knowledge-based economy in the world. This intention should be accompanied by the appropriate optimization and decision support system (Brauers, Baležentis \& Baležentis, 2012) ${ }^{2}$. A number of scholars have devoted their research to problems of forecasting the economy functioning indicators. For example, some of them (Simionescu, Dobeš, Brezina, Gaal, $2016)^{3}$ suggested using modelling based on group data models for this purpose, others (Bruno, 2005 $5^{4}$ Gayer, 2006 ${ }^{5}$ ) suggested dynamic unbalanced models of panel data. At the same time, analytical alignment models are most often used for forecasting with correlation and regression analysis methods (Schneider, Hommel, \& Blettner, 2010) ${ }^{6}$, which make it possible to construct the dependence of the certain indicator change on the time factor and, on this basis, to determine the indicator forecast values.

Although a lot of attention in economic research is devoted to economic and mathematical forecasting problems, certain aspects of forecasting economic and mathematical models need to be refined as the basis for improving development management not only of the individual country but also of supranational entities, which is the European Union.

To achieve this objective, methods of dynamic analysis should be used to outline the main trends of change in key functioning parameters of Ukraine and the European Union as the system, methods of analytical alignment on the basis of correlation-regression modelling should be used to formalize the revealed trends.

The main objective of the study is to identify the main tendencies of the European Union functioning parameters, to predict the indicators of its development as the complex dynamic socio-economic system and, on this basis, to decide on EU development management drivers. To achieve this objective, it is necessary to analyse the main indicators of the European Union functioning parameters, to use analytical

\footnotetext{
${ }^{2}$ Karel, W., Brauers, M., Baležentis, A. \& Baležentis T. (2012). European Union member states preparing for EUROPE 2020. An application of the MULTIMOORA method, Technological and Economic Development of Economy, 18 (4), 567-587. doi: https://doi.org/10.3846/20294913.2012.734692

3 Simionescu, M., Dobeš, K., Brezina, I., \& Gaal, G. (2016). GDP Rate in The European Union: Simulations Based On Panel Data Models. Scientific Papers Journal of international studies, 9 (3), $191-202$. doi: https://doi.org/10.14254/2071-8330.2016/9-3/15

${ }^{4}$ Bruno, G. S. F. (2005). Estimation and inference in dynamic unbalanced panel-data models with a small number of individuals. The Stata Journal, 5, 473-500. Retrieved from http://www.statajournal.com/ article.html?article=st0091

${ }^{5}$ Gayer, C. (2006). Forecast Evaluation of European Commission Survey Indicators, Journal of Business Cycle Measurement and Analysis, 2005/2. doi: https://doi.org/10.1787/jbcma-v2005-art2-en

${ }^{6}$ Schneider, A., Hommel, G., \& Blettner, M. (2010). Linear Regression Analysis - part 14 of a series on evaluation of scientific publications. Dtsch Arztebl Int; 107 (44): 776-82. doi: https://doi.org/ 10.3238/arztebl.2010.0776
} 
equalization methods based on correlation-regression modelling of forecasting the development indicators of the European Union as a system and, on this basis, to develop recommendations for improving the management of European Union development using the most appropriate type of management drivers.

The European Union is a complex supranational entity that has all of the signs of a complex open socio-economic system. In this regard, the functioning of the European Union, like any other system, can be characterized by a number of parameters, the main of which are functioning results. In turn, determining the functioning results at the level of such entities as the European Union means assessing the level and dynamics of the total GDP as a whole, the average GDP in the countries that are part of EU, and the GDP per capita. That is, the last two indicators that create the basis for the comparison between European Union countries and other countries in order to identify the level of development of these countries and to determine future directions for their development management. The dynamics of the total GDP in the European Union (million euro) for 2005-2017 is shown in Fig. 1.

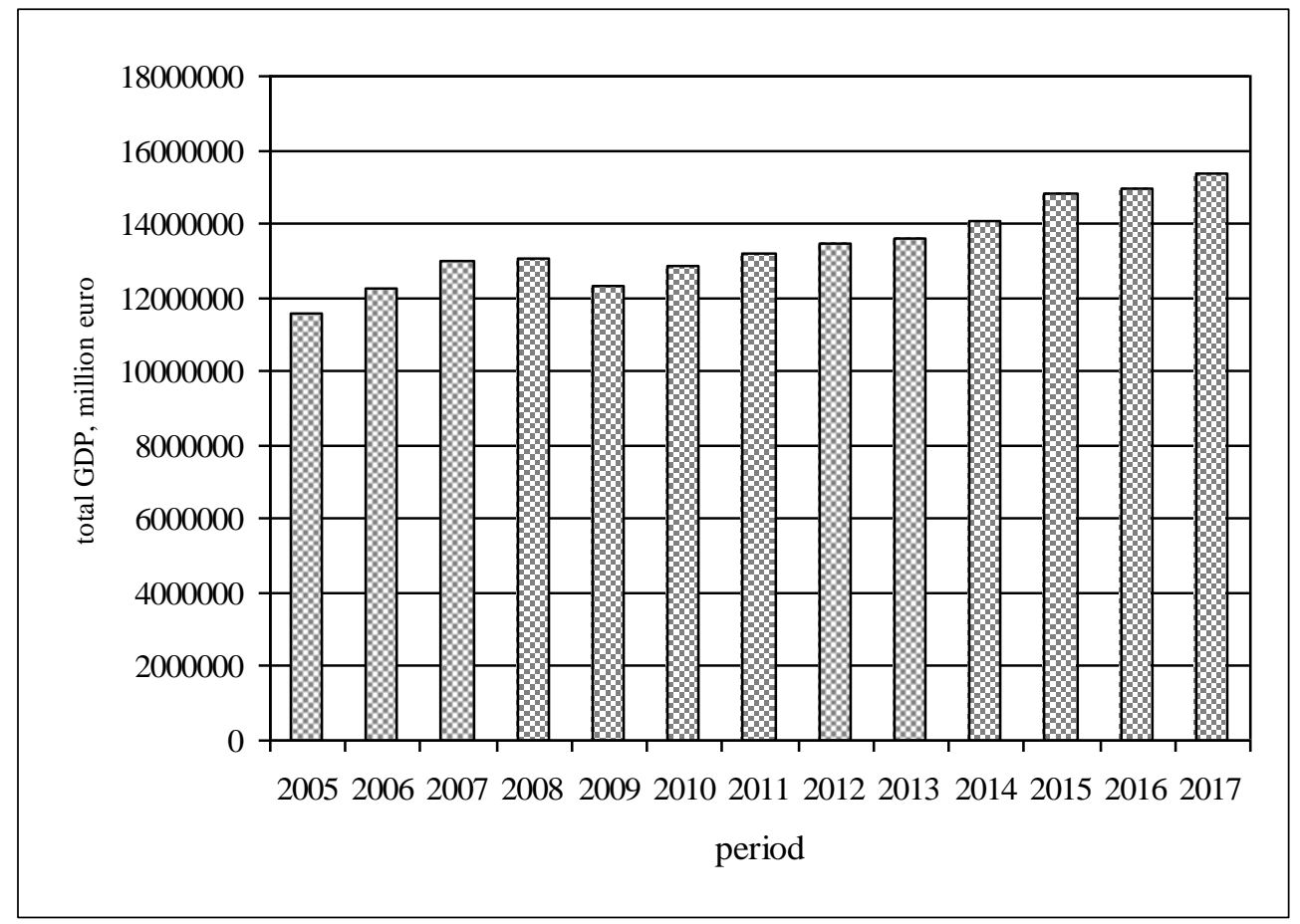

Fig. 1. The dynamics of total GDP in the European Union (million euro) for 2005-2017 ${ }^{7}$

\footnotetext{
7 Eurostat (2018). Your key to European Statistic. Retrieved from: https://ec.europa.eu/eurostat/ data/database.
} 
As can be seen from Figure 1, the total GDP in the EU countries had a rather pronounced upward trend. The reduction of this indicator had been observed only in 2009, which by most researchers is associated with the crisis processes' dominance in the world economy. Some scientists, in particular, find the origins of crisis process development in the financial sector, which, in their opinion, plays the decisive role in the economy, acting as a link between the part of the economy that requires funds and the part that can provide them in the form of investments (Acharya, Philippon, Richardson, \& Roubini, 2009) ${ }^{8}$. That is the exceptional role of the financial sector that had led to the problems that appeared in the financial sphere and spread to other spheres of economic life with lightning speed. This position is no exception. For example, other scientists (Zych, Ortega-Ruiz, López, \& Llorent, 2015) ${ }^{9}$, using the expert survey methodology while researching factors leading to the global crisis, found out that the crisis arose primarily in the financial sphere and had been caused by weaknesses in financial institution management (both internal and external) and financial institution functioning.

The causes and consequences of the global economic crisis had been considered by other scientists (Rapoport \& Gerts, 2010) ${ }^{10}$ as well. In their researches, authors consider the recent global crisis as a combination of several regional crises that occurred simultaneously but for different reasons. However, these crises have a common cause, which lies in the fact that developed countries, as a rule, maintain a certain level of social security without increasing real output. That had been this policy that led to a trade deficit and partial destruction of market mechanisms and stimulated the crisis process development. Some scientists' opinion should be accepted that a deep financial crisis had been not only a period of capital loss but also a process of adaptation, manifested in price changes (in particular, the deployment of deflationary processes) and the real consequences associated with recession and low employment (Vieira 2011) ${ }^{11}$. In addition, this period

\footnotetext{
${ }^{8}$ Acharya, V., Philippon, T., Richardson, M., \& Roubini, N. (2009). The Financial Crisis of 2007-2009: Causes and Remedies. Financial Markets. Institutions \& Instruments, 18 (2), 89-137. doi: https://doi.org/10.1111/j.1468-0416.2009.00147_2.x

${ }^{9}$ Zych, I., Ortega-Ruiz, R., López, M. M., \& Llorent, V. J. (2015). Causes and Solutions for the Economic Crisis According to the International Scientific Community. Universitas Psychologica, 14 (1), 367-379, doi: https://doi.org/10.11144/Javeriana.upsy14-1.csec

${ }^{10}$ Rapoport, A., \& Gerts, A. (2010). The Global Economic Crisis of 2008-2009, Problems of Economic Transition, 53:6, 45-62. doi: https://doi.org/10.2753/PET1061-1991530603

${ }^{11}$ Vieira, F. V. (2011). The new international financial crisis: causes, consequences and perspectives, Brazilian Journal of Political Economy, 31 (2 (122)), 217-237. doi: https://doi.org/10.1590/S010131572011000200003
} 
can be described as a period of anxiety and the end of illusions, including those that associated with the state's opposition to the market, the rejection of the regulatory role of the state in modern economic processes. It was the awareness of the need for at least moderate government intervention in market processes and that became the basis for the reorientation of the political course of developed countries, including countries of the European Union, in order to bring their economies out of the crisis. Such a reorientation allowed overcoming the crisis processes and putting the economy of the European Union countries on the path of sustained long-term growth. Such growth was manifested in GDP raise, the total value of which in the European Union countries for the study period (2005-2017) increased to $3,759,891,700,000$ Euros or to $32.44 \%$. The last year of the study period had been marked by the growth of total GDP in the EU countries. So, this indicator increased by $413,455.1$ million euros or by $2.77 \%$ in comparison to the previous year.

It is interesting to compare the dynamics of Ukraine's GDP with the dynamics of average GDP within EU countries (study period).

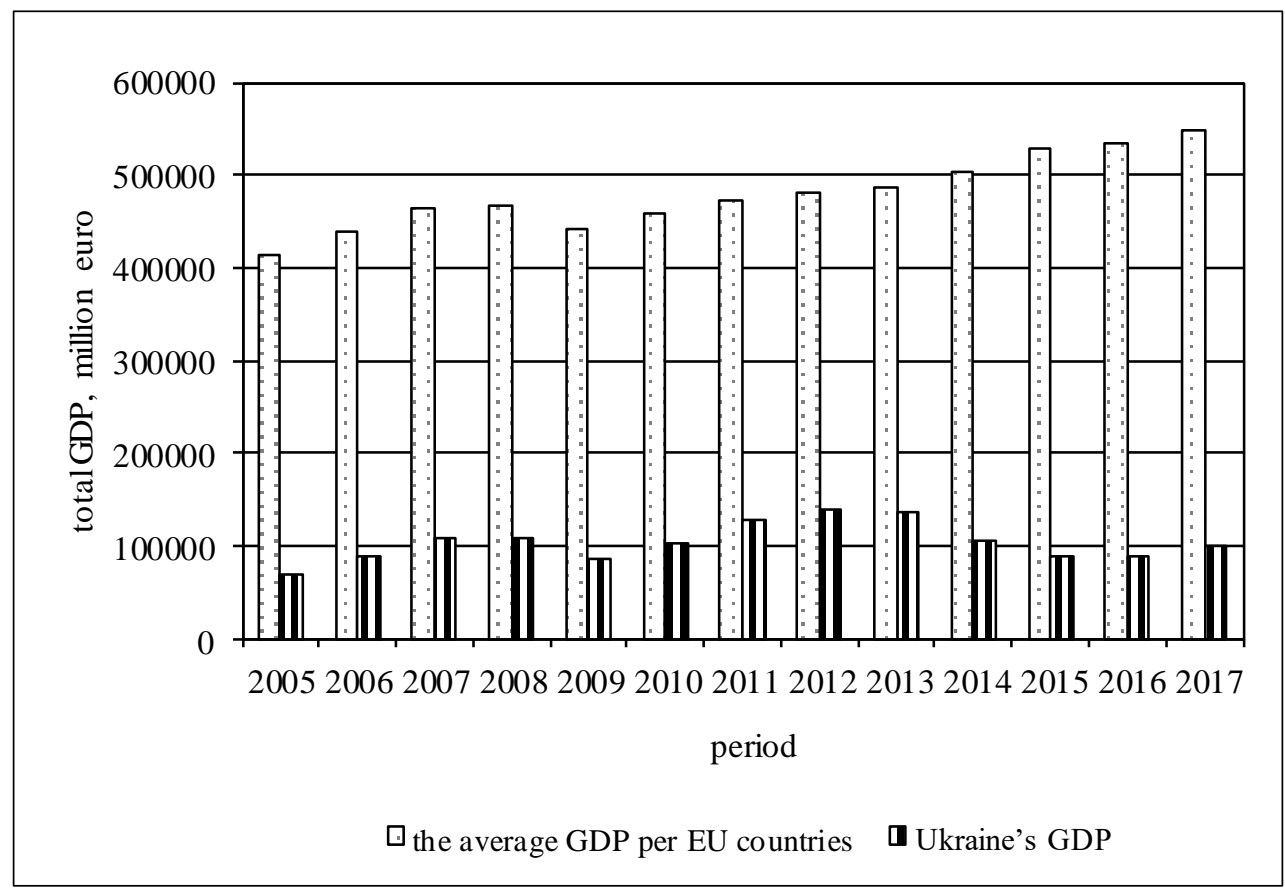

Fig. 2. Comparison of Ukraine's GDP with the average GDP per EU countries for 2005-2017 ${ }^{12} 13$

12 Eurostat (2018). Your key to European Statistic. Retrieved from: https://ec.europa.eu/eurostat/ data/database. 
As can be seen from Fig. 2, Ukraine's GDP is significantly less than the average level of the European Union countries' GDP and, moreover, it differs considerably. So, if during the study period, the average value of GDP in the EU countries had a tendency to rise (with a slight decrease in 2009 due to a number of the reasons discussed above), then there was no clear trend in GDP in Ukraine. The reason for this is significant fluctuations of the indicator that reflected visually in Fig. 2. Not only 2009 was characterized with the fall but also 2014-2016 when the serious domestic political situation in the country led to the annexation of the Autonomous Republic of Crimea and the occupation of certain regions of the country.

In many ways, the lack of tangible improvements in the country depends on the policies of the strongest players in the political arena (Nix, 2014 ${ }^{14}$; Nitoiu, $2016^{15}$ ). Thus, the first one among these scientists emphasizes the need for active intervention by the world community in response to Russia's actions in the Crimea and eastern Ukraine (Nix, 2014). But some scientists believe that the root cause of the conflict in the east of Ukraine was precisely the mutual reinforcement of the European Union and Russia presence in the post-Soviet space. Both players seek to retain their influence in the region to maintain their status. Therefore, instead of searching for a mutually beneficial and stable agreement that would give decisive importance to the interests of Ukraine, the EU and Russia entered the stage of hidden resistance, which only increases differences and deepens the conflict (Nitoiu, 2016). Considering the position of Ukraine as a participant in the political game of titans (Russia, the United States, the European Union) on the world stage, it should be noted that, for a long time, Ukraine had a cautious policy of balancing between East and West. Thus, despite the European benchmark proclamation for Ukraine, a policy of deepening economic, energy, and political dependence on Russia was pursued, and the conflict was further developed (Wolczuk, 2016) ${ }^{16}$. The author emphasizes that the escalation of the conflict to a certain extent contributed to the self-

\footnotetext{
${ }^{13}$ State Statistics Service of Ukraine (2018). Statistic Information. Retrieved from: http://www.ukrstat.gov.ua (in Ukrainian)

${ }^{14}$ Nix, S. B. (2014). Responding to the Russian Invasion of Crimea: Policy Recommendations for US and European Leaders. European View, 13 (1), 143-152. doi: https://doi.org/10.1007/s12290-014-0297-3

${ }^{15}$ Nitoiu, C. (2016). Russia and the EU's quest for status: the path to conflict in the post-Soviet space, Global Affairs, 2:2, 143-153, doi: https://doi.org/10.1080/23340460.2016.1163775

${ }^{16}$ Wolczuk, K. (2016). Ukraine and Europe: Reshuffling the boundaries of order. Thesis Eleven, 136 (1), 54-73. doi: https://doi.org/10.1177/0725513616667666
} 
identification of Ukraine as a state oriented towards Europe. However, she notes that against the background of reducing cultural differences between Ukraine and the EU countries, geopolitical and economic barriers to Ukraine integration into the European community are still tangible. To support this conclusion, it is possible to cite at least the fact that at the beginning of the study period, the average GDP in the European Union countries exceeded the level of Ukraine's GDP by $344,603,200,000$ euros, while at the end of the study period, the excess amounted to $447,460,200,000$ euros. That obviously had an impact on the well-being of EU and Ukraine residents, the level of which can be compared based on the analysis of the level and dynamics of GDP per capita (Fig. 3).

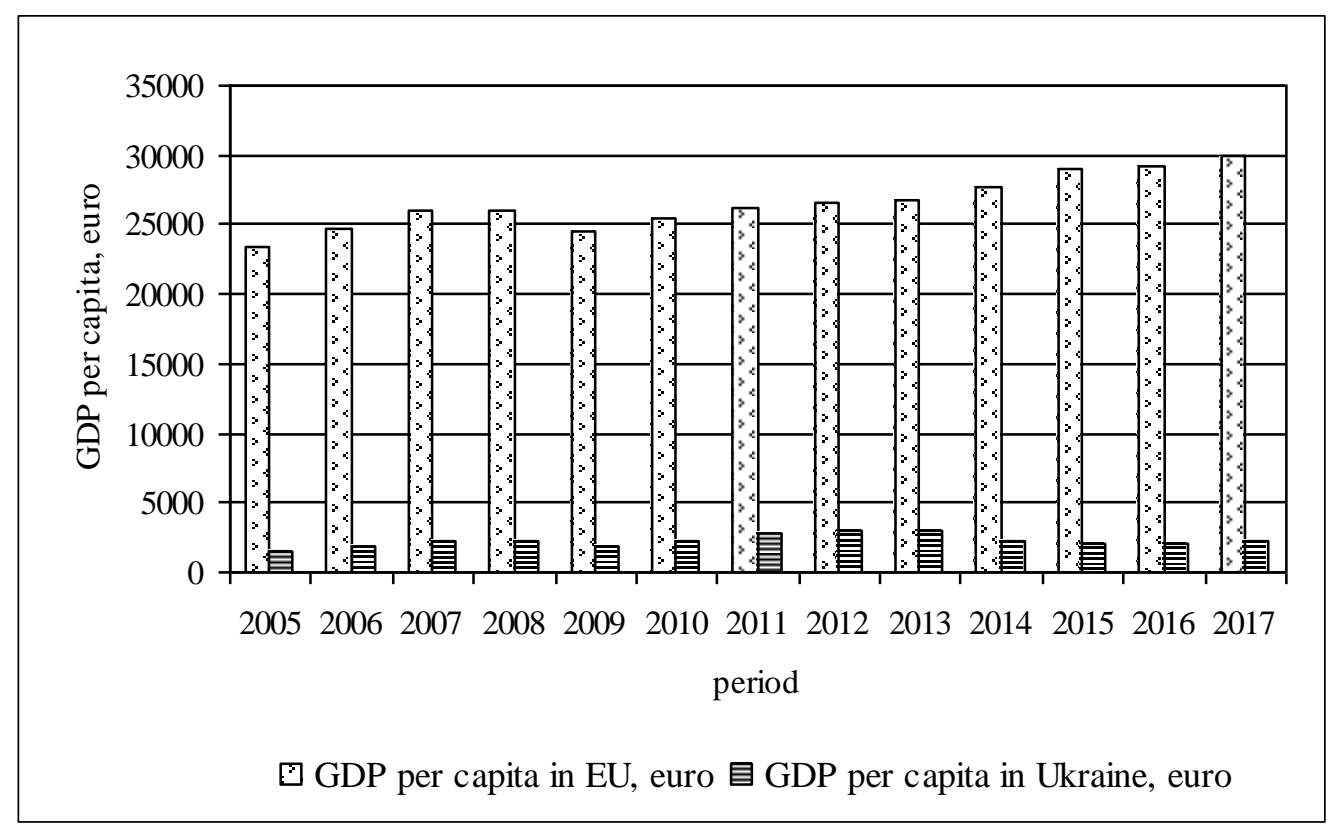

\section{Fig. 3. Comparison of GDP per capita in Ukraine and EU countries for 2005-2017}

As can be seen from the data of Fig. 3, Ukraine's lagging behind the level of welfare from the EU countries can be considered catastrophic because the GDP per capita in the EU countries exceeds the level of the similar indicator in Ukraine 14-16 times. Overall, the survey showed that the EU countries are developing with a much higher level of stability than Ukraine. Thus, according to our calculations, the adaptability of the national economy of Ukraine as a socio-economic system to the environmental changes is 0.817 , while for the EU countries it is 1,101 . 
Regardless of what is the situation in the analysed socio-economic system, development management may be one of the three styles of management decision-making that is recommended to be chosen depending on the adaptability of the socio-economic system. So, if the adaptability of the system is low, then it is more appropriate to follow the cautious style of making managerial decisions; under the condition of normal adaptability of the system optimal style is optimal; under the condition of sufficient adaptability of the system, the style of making managerial decisions can be adventurous (risky).

The decision-making style influences which of the scenarios of development in the forecast period will serve as a benchmark for determining the reaction rate of the system and selecting the appropriate type of driver for it.

So, if we talk about development management for the EU countries, then it, as well as the management of the development of the national economy of Ukraine, should take place on the basis of management drivers. But, as the calculations showed, the level of adaptability of the European Union is sufficient, then the choice of the type of a management driver should be based on the optimistic development scenario (for the national economy of Ukraine, it is recommended to take the pessimistic scenario as the base one).

\subsection{Justification of the choice of the driver for development management and its structural elements}

Any driver requires the definition of methods that should be used to achieve the best performance. As noted earlier, such methods are divided into three groups:

- legal - a set of ways of influencing the subject of management on the object of management through the establishment and legislative consolidation of rules (including legal norms, legal relations, legal acts);

- economic - a set of tools and tools that purposefully affect the creation of conditions for the functioning and development of entrepreneurship (including pricing, financing, lending, taxation);

- administrative - a system of methods and techniques of organizational and administrative actions, which is used for the organization and coordination of management objects in order to perform the tasks (including organizational regulation, organizational regulation, organizational and methodological instruction, binding requirements, conciliation actions, recommendations). 
Different types of drivers are dominated by different methods:

- for starting - all three types of methods (legal, administrative, economic), the combination of these methods allow the system to operate;

- for the generating - administrative and economic, as a slow reaction of the system is possible only if the legal framework of its functioning has already been created and needs only a certain correction, while the administrative and economic methods allow forming the necessary reaction to the impulses of development;

- for accelerating - economic methods since the moderate reaction is possible only in the formation of the regulatory environment and the high level of organization of the system while the need for stimulating development, which can be achieved by economic methods, is at the forefront;

- $\quad$ for the transforming - all of three types of methods since that is used in the rapid reaction system, in which the regulatory framework and established organizational communications quickly lose their relevance, and therefore, this type of driver, as well as the startup leads the system not only into action but already on a new qualitative level).

We have developed an approach to the choice of the type of control drivers for the development of the socio-economic system (starting, generating, accelerating, transforming), based on the results of forecasting, taking into account the degree of adaptability of the system in the chosen scenario of development and determining the speed of its reaction to the impact of impulses, which allows choosing the appropriate kind of the management driver, the application of which is most appropriate in the prevailing conditions (Fig. 4).

An approach to choosing a driver type (starting, generating, accelerating, transforming) based on the results of the forecasting for the selected scenarios, taking into account the degree of system adaptability of the system, is developed and empirically tested on the national and international level, and it allows choosing the appropriate type of management driver, the application of which is the most acceptable in the prevailing conditions.

A reason for the choice of the type of development management driver includes forecasting. In order to obtain a more accurate forecast, a model of analytical alignment was built for general indicators of the economic, social, and environmental development of the European Union countries using various dependence functions: 


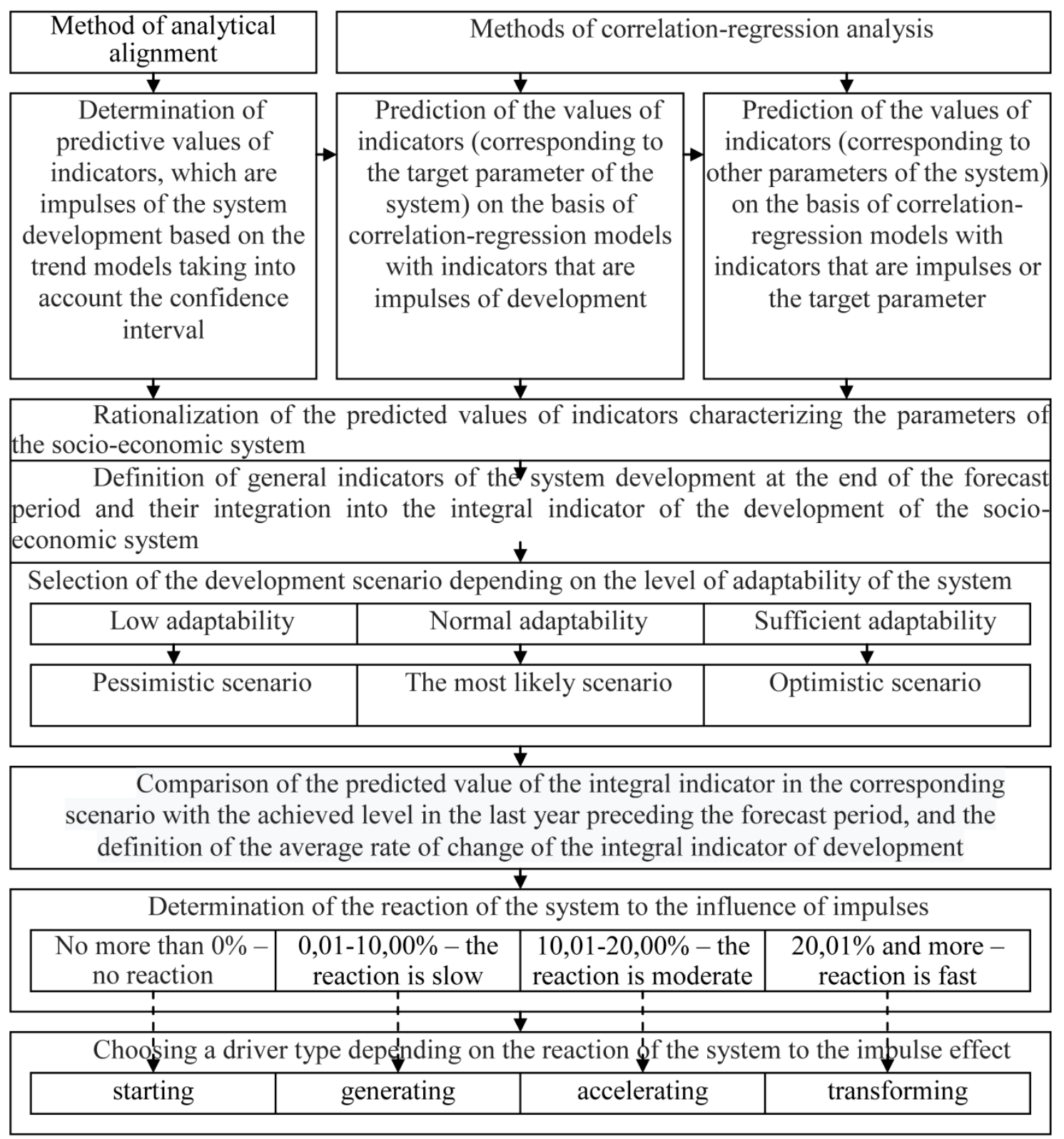

\section{Fig. 4. An approach to the choice of the type of management drivers for the development of the socio-economic system}

- linear;

- logarithmic;

- degree;

- exponential;

- polynomial.

The built models passed tests for adequacy and reliability with respect to standard criteria; all the built models which demonstrate better connectivity between the output indicator and the indicator influenced by (in this case, the time factor) have been chosen: 


\section{Economic Development Trend Line Model}

$$
y_{1}=0,1076 \cdot \ln x+0,6564,
$$

$y_{1}$ - indicator of the European Union economic development ;

$x$ - a conditional number of the study period.

The proposed model has a correlation coefficient of 0.861 . It means that there is a strong link between the output indicator and the time factor, which explains its change.

2. Social Development Trend Line Model:

$$
y_{1}=-0,0011 \cdot x^{2}+0,0152 \cdot x+0,7584,
$$

$y_{1}$ - indicator of the European Union social development;

$x$ - a conditional number of the study period.

The proposed model has a correlation coefficient of 0.856 . It means that there is a strong link between the output indicator and the time factor, which explains its change.

3. Ecological Development Trend Line Model

$$
y_{1}=0,342 \cdot x^{0,1252},
$$

$y_{1}$ - indicator of the European Union ecological development;

$x$ - a conditional number of the study period.

The proposed model has a correlation coefficient of 0,856 . It means that there is a strong link between the output indicator and the time factor, which explains its change.

Through the built models, European Union's economic, social, and environmental development forecast values by 2020 have been determined and it was found that according to the optimistic scenario, the integrated development indicator calculated on their basis will grow by an average $10.5 \%$. The choice of the driver also depends on the socio-economic system reaction rate to changes in the external environment. So, if the value of the average rate of change of the integral development indicator is 0 , it means that there is no reaction (you should choose a starting driver), if it is from 0 to $10 \%$ it means a slow reaction (you should choose a generating driver), from 10 to $20 \%$ it means a moderate reaction (you should choose an accelerating driver), if it is more than $20 \%$ it means quick response (you should choose a supporting driver). According to calculations of the average rate of change in the integral development indicator in Ukraine, there is a slow reaction to the change in the external environment, and therefore, there 
is a need to use a generating driver. Generating management driver is the key to developing a strategy for managing the development of the national economy of Ukraine. The structure of the generating driver is shown in Figure 5.

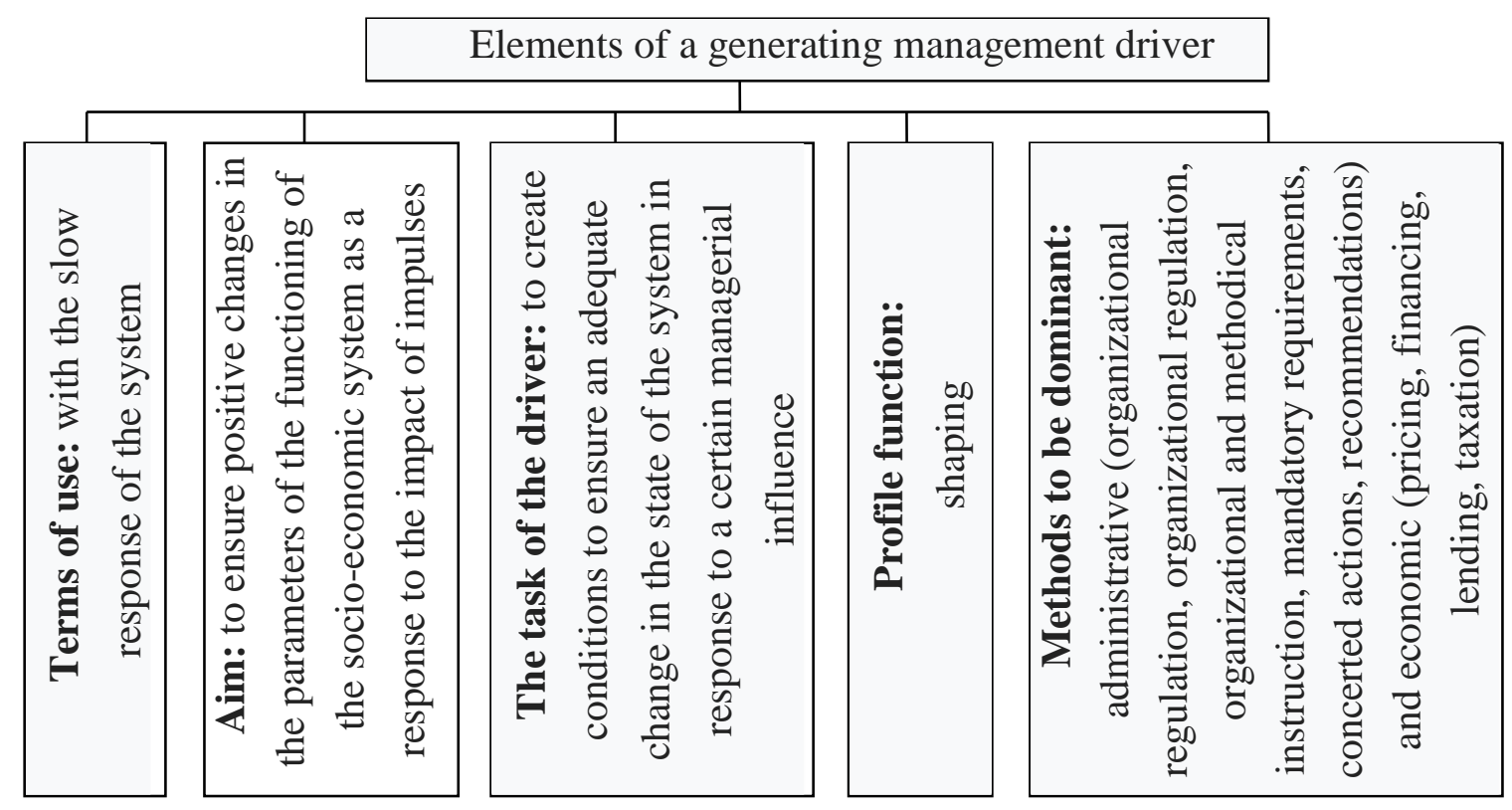

\section{Fig. 5. The structure of the generating driver for managing the development of the national economy}

At the same time, for the EU countries, an accelerating driver should be used because, unlike the national economy of Ukraine, for the European Union as a system, a moderate reaction is typical according to the interpretation of the average rate of change of the integral development indicator, and therefore, it is necessary to use an accelerating development management driver.

The structure of the accelerating development management driver is presented in Fig. 5. The main difference between the accelerating and the generating drivers is in the influence, target, and functional units. The generating driver for development management is mainly aimed at creating conditions to ensure the timely change of the system in response to a certain influence. At the same time, the main function of this type of development management driver is formative, and the methods that should dominate to accomplish the task and functions are mainly administrative and economic, with a significant advantage of the first. But the main function of the accelerating development management driver is promotional. 


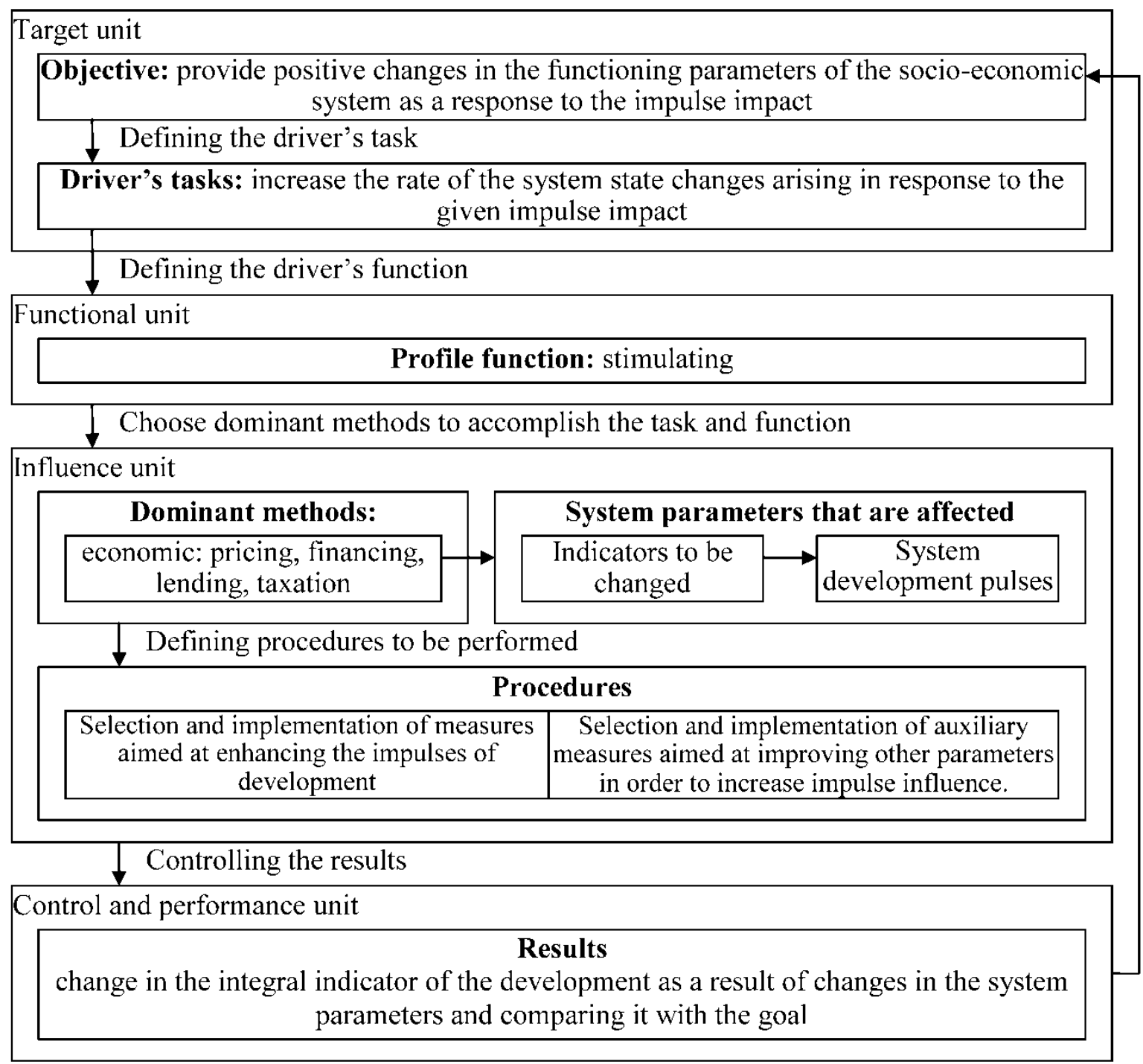

Fig. 6. Accelerating Development Driver Pattern

Source: developed by the author

As can be seen from Fig. 6, the main objective of the accelerating control driver is to ensure positive changes in the parameters of the socio-economic system functioning as a result of accelerating the reaction rate to the impact of development impulses. At the same time, it is generally acknowledged that a combination of investment and innovation should be the impetus for the development of GDP. Thus, a number of scientists (Kacprzyk, \& Doryń, 2017) ${ }^{17}$ confirm in their research that, despite the relatively high level of performance indicators

\footnotetext{
${ }^{17}$ Kacprzyk, A., \& Doryń, W. (2017). Innovation and economic growth in old and new member states of the European Union, Economic Research-Ekonomska Istraživanja, 30 (1), 1724-1742. doi: https://doi.org/10.1080/1331677X.2017.1383176
} 
of the European Union, the differences in the gross domestic product (GDP) per capita remain significant in all European countries. This raises the question of possible measures that can be taken to narrow this gap. Although the discussion of the determinants of development is quite a popular topic, there is a growing consensus between economists and politicians that it is the investment in knowledge that is the centre of the endogenous growth process that is the prerequisite for achieving consistently high growth rates. The hypothesis about the role of innovation in ensuring high rates of growth, which is a sign of accelerated economic development of the country, has been confirmed in the work of other scholars (Madsen, 2008 ${ }^{18}$; Ang, \& Madsen, 2011 ${ }^{19}$ ). Scientists, using data from six Asian economic countries, demonstrated an amazing pace of economic development in the second half of the twentieth century, investigated how much their rate of change in indicators was based on research and development. Research has proven that Schumpeter's ideas about recognizing innovation as the determining factor for development are fully fair. In another research paper (Sterlacchini, $2008^{20}$ ), the author, although he recognizes the role of innovation as one of the development factors, claims that it plays a big role in developed countries with a high level of GDP.

Paying tribute to the role of innovation and investment in the economy, some scientists tried not only to confirm it using various methods of economic and mathematical modelling but also to determine the factors affecting the success of their implementation. Empirical results obtained by individual scientists (Rodríguez-Pose, \& Crescenzi, $2008^{21}$ ) show the meaning in this context of the interaction between local and external research, on the one hand, with local and external socioeconomic and institutional conditions, on the other. They also point to the importance of transferring economically productive knowledge since it is the diffusion of innovations that has the greatest effect. It is with these impulses that development management must be exercised.

\footnotetext{
${ }^{18}$ Madsen, J. B. (2008). Economic growth, TFP convergence and the world export of ideas: A century of evidence. The Scandinavian Journal of Economics, 110, 145-167. doi: https://doi.org/10.1111/j.14679442.2008.00530.x

${ }^{19}$ Ang, J. B., \& Madsen, J. B. (2011). Can second-generation endogenous growth models explain the productivity trends and knowledge production in the Asian miracle economies? Review of Economics and Statistics, 93, 1360-1373. doi: https://doi.org/10.1162/REST_a_00126

${ }^{20}$ Sterlacchini, A. (2008). R\&D, higher education and regional growth: Uneven linkages among European regions. Research Policy, 37, 1096-1107. doi: https://doi.org/10.1016/j.respol.2008.04.009

${ }_{21}$ Rodríguez-Pose, A., \& Crescenzi, R. (2008). Research and development, spillovers, innovation systems, and the genesis of regional growth in Europe. Regional Studies, 42, 51-67. doi: https://doi.org/10.1080/00343400701654186
} 


\section{CONCLUSIONS}

Thus, it has been found that the characteristics of economic development in the context of the influence of global processes are determined by the presence of positive aspects. The calculations showed that key indicators on the parameter of the functioning results of the EU countries as a socio-economic system have pronounced upward trends. This is obviously a manifestation of the stability of the pace of development of the European Union countries, especially in comparison with the unstable situation in Ukraine. Through the method of analytical alignment based on the correlation-regression modelling, trend models were built summarizing the economic, social, and environmental development of the EU countries. The results of the built models use allowed justifying the use of an accelerating driver for managing the development of the European Union and noting the differences from the generating driver, which is recommended for Ukraine.

Based on the results of forecasting, a further development strategy for the European Union can be developed, in which the need to use a management driver focused on stimulating development by increasing investments and innovations, which act as development impulses, should be taken into account.

\section{SUMMARY}

The article generalizes arguments and counter-arguments within scientific discussion concerning the problems of the choice based on the results of forecasting of development management drivers as a specific mechanism of development management of national and international systems.

The main purpose of the research is identifying the main trends of parameters of Ukrainian and European economies functioning, development of indicators forecasting as complicated dynamic economic and social system and establishing priorities of development management of the national economy compared with European Union based on proposed development management drivers.

The scientific problem solution is of great urgency because development providing spontaneous or controlled crossing from one unique condition (state) to another through change process is an important essential characteristic of any social and economic system of Ukrainian and European national economies. 
The purpose of development should be harmonization of its three components: economic, social, and ecological. In order to achieve this purpose, it is necessary to improve development management based on forecasting.

The structure of management drivers that are to be used in different conditions was examined. The choice of driver type of development management for the European Union and Ukraine was made based on forecasting; the main impulses of their development were determined.

The research empirically confirmed and theoretically proved that for European Union countries, it is necessary to use the accelerating driver of development management aimed at stimulating function while managing their development.

The results of the research can be useful for further forecasting of the European Union development as a social and economic system and designing of the European Union's development strategy. Using accelerating driver of management should become its compulsory instrument allowing activating impetus of their development such as investment and innovation.

\section{REFERENCES}

1. Kranjac, M., Sikimić, U., Tomić, S., \& Vapa-Tankosić, J. (2017). The Contribution of EU Funds to Wellbeing and Sustainable Development in Central European Countries. European Journal of Sustainable Development, 6 (1), 85-102. doi: https://doi.org/10.14207/ ejsd.2017.v6n1p85

2. Karel, W., Brauers, M., Baležentis, A. \& Baležentis T. (2012). European Union member states preparing for EUROPE 2020. An application of the MULTIMOORA method, Technological and Economic Development of Economy, 18 (4), 567-587. doi: https://doi.org/ 10.3846/20294913.2012.734692

3. Simionescu, M., Dobeš, K., Brezina, I., \& Gaal, G. (2016). GDP Rate In The European Union: Simulations Based On Panel Data Models. Scientific Papers Journal of international studies, 9 (3), 191-202. doi: https://doi.org/10.14254/2071-8330.2016/9-3/15

4. Bruno, G. S. F. (2005). Estimation and inference in dynamic unbalanced panel-data models with a small number of individuals. The Stata Journal, 5, 473-500. Retrieved from: http://www.statajournal.com/ article.html? article $=$ st0091 
5. Gayer, C. (2006). Forecast Evaluation of European Commission Survey Indicators, Journal of Business Cycle Measurement and Analysis, 2005/2. doi: https://doi.org/10.1787/jbcma-v2005-art2-en

6. Schneider, A., Hommel, G., \& Blettner, M. (2010). Linear Regression Analysis - part 14 of a series on evaluation of scientific publications. Dtsch Arztebl Int; 107 (44): 776-82. doi: https://doi.org/ 10.3238/arztebl.2010.0776

7. Eurostat (2018). Your key to European Statistic. Retrieved from: https://ec.europa.eu/eurostat/data/database.

8. Acharya, V., Philippon, T., Richardson, M., \& Roubini, N. (2009). The Financial Crisis of 2007-2009: Causes and Remedies. Financial Markets. Institutions \& Instruments, 18 (2), 89-137. doi: https://doi.org/10.1111/j.1468-0416.2009.00147_2.x

9. Zych, I., Ortega-Ruiz, R., López, M. M., \& Llorent, V. J. (2015). Causes and Solutions for the Economic Crisis According to the International Scientific Community. Universitas Psychologica,14 (1), 367-379. doi: https://doi.org/10.11144/Javeriana.upsy14-1.csec

10. Rapoport, A., \& Gerts, A. (2010). The Global Economic Crisis of 2008-2009, Problems of Economic Transition, 53:6, 45-62. doi: https://doi.org/10.2753/PET1061-1991530603

11. Vieira, F. V. (2011). The new international financial crisis: causes, consequences and perspectives, Brazilian Journal of Political Economy, 31 (2 (122)), 217-237. doi: https://doi.org/10.1590/S010131572011000200003

12. Eurostat (2018). Your key to European Statistic. Retrieved from: https://ec.europa.eu/eurostat/data/database.

13. State Statistics Service of Ukraine (2018). Statistic Information. Retrieved from: http://www.ukrstat.gov.ua (in Ukrainian)

14. Nix, S. B. (2014). Responding to the Russian Invasion of Crimea: Policy Recommendations for US and European Leaders. European View, 13 (1), 143-152. doi: https://doi.org/10.1007/s12290014-0297-3

15. Nitoiu, C. (2016). Russia and the EU's quest for status: the path to conflict in the post-Soviet space, Global Affairs, 2:2, 143-153. doi: https://doi.org/10.1080/23340460.2016.1163775

16. Wolczuk, K. (2016). Ukraine and Europe: Reshuffling the boundaries of order. Thesis Eleven, 136 (1), 54-73. doi: https://doi.org/10.1177/0725513616667666 
17. Kacprzyk, A., \& Doryń, W. (2017). Innovation and economic growth in old and new member states of the European Union, Economic Research-Ekonomska Istraživanja, 30 (1), 1724-1742. doi: https://doi.org/ 10.1080/1331677X.2017.1383176

18. Madsen, J. B. (2008). Economic growth, TFP convergence and the world export of ideas: A century of evidence. The Scandinavian Journal of Economics, 110, 145-167. doi: https://doi.org/10.1111/ j.1467-9442.2008.00530.x

19. Ang, J. B., \& Madsen, J. B. (2011). Can second-generation endogenous growth models explain the productivity trends and knowledge production in the Asian miracle economies? Review of Economics and Statistics, 93, 1360-1373. doi: https://doi.org/10.1162/ REST_a_00126

20. Sterlacchini, A. (2008). R\&D, higher education and regional growth: Uneven linkages among European regions. Research Policy, 37, 1096-1107. doi: https://doi.org/10.1016/j.respol.2008.04.009

21. Rodríguez-Pose, A., \& Crescenzi, R. (2008). Research and development, spillovers, innovation systems, and the genesis of regional growth in Europe. Regional Studies, 42, 51-67. doi: https://doi.org/ $10.1080 / 00343400701654186$

\section{Information about the author:} Kononova I. V.

$\mathrm{PhD}$ in Economic Sciences, Associate Professor,

Department of Accounting, Economics and Personnel Management of Enterprise, Prydniprovska State Academy of Civil Engineering and Architecture, Ukraine 